\title{
Green Credit Rises the Financial Performance of Commercial Bank--A Case Study on Industrial Bank
}

\author{
Yue Zhang \\ School of Economics and Management, Nanjing Tech University, Nanjing 211816, China. \\ Moonnzhang@163.com
}

\begin{abstract}
Green environmental protection is an important means to realize the economic sustainable development in recent years. The green financial wind is quietly rising. To carry out the green credit will become the focus of the credit business development in future. This study uses the financial data of Industrial Bank from 2005 to 2017, empirically testing the impact of commercial bank green credit on financial performance by analyzing the return on assets. The conclusion shows that green credit has a positive impact on bank's financial performance, providing a basis for the continued development of green credit. In view of the fact that the current products of this business are not rich enough and the management system is not perfect, this study puts forward two reasonable suggestions: innovative green credit products to meet market demand; improve the internal organization structure of banks and the level of green credit management.
\end{abstract}

Keywords: Green credit, financial performance, industrial bank.

\section{Background}

Since the State Environmental Protection Administration, the People's Bank of China, and the China Banking Regulatory Commission jointly issued the "Opinions on Implementing Environmental Protection Policies and Regulations to Prevent Credit Risks" in July 2007, green credit has developed rapidly. Represented by state-owned commercial banks such as ICBC and ABC, more than 29 banks have successively joined the ranks of green credit, practicing the concept of green development with practical actions. In 2017, the banking industry's green credits exceeded 14 billion, covering many service areas (energy service financing, clean energy financing, carbon finance, etc.), and also supporting more than 20,000 Financing energy efficiency projects.

When banks carry out green credit, providing financial support for corporate environmental protection, can they create new profit growth points for themselves? Scholars have explored the problem theoretically. Most of them hold a positive attitude and believe green credit is a way to effectively manage bad debt risk, improve business performance (DX He, 2007). According to reputation mechanism, Miles \& Coven (2000) hold the view that green credit can enhance the competitiveness of banking financial institutions and gain financial advantages. Despite the many advantages, green credit projects are usually small and time-consuming, with some uneconomic and uncertainties, and it's difficult to estimate the risks. The "two highs and one surplus" industries are always the main source of profit for banks, which can bring higher customer current value (XH Shen, 2012).

Therefore, this paper believes that the development of green credit has become an option for commercial banks to enhance profitability and improve financial performance. Industrial Bank is China's first "Equator Bank", and green is a unique label of the bank. Industrial Bank adheres to the "scientific and sustainable" development concept, constantly innovates financial products and leads a new wave of green finance. Take Industrial Bank as a case, this paper analyzes the development of Green Credit of Industrial Bank, using empirical methods to explore the effectiveness of this business.

\section{Case Introduction}

As a pioneer and advocate of the green financial concept, Industrial Bank took the energy-saving and emission-reduction financing business as the entry point, taking the lead in opening up the domestic green financial market, and embarked on a road of characteristic development with “justification and benefit". In May 2006, Industrial Bank and IFC jointly launched China's first green 
credit project. Subsequently, Industrial Bank began to set up new financing standards to guide the flow of funds into the green, energy-saving and emission-reducing industries. Then in 2008, it officially publicly promised to fulfill the "Equator Principles" and became China's first "Equator Bank", taking the initiative in the field of sustainable development.

In the 12 years of green finance, Industrial Bank has integrated its own green financial development into the process of national ecological civilization construction, and continued to innovate around the needs of physical enterprises, and has embarked on a road of "green to gold" development. The green credit system covers three major areas of low-carbon economy, circular economy and ecological economy, involving energy, greening, sewage treatment and industrial energy conservation and emission reduction. By referring to the Annual Report, the green credit scale and net profit of the Industrial Bank from 2006 to 2017 are shown in Figure 1.

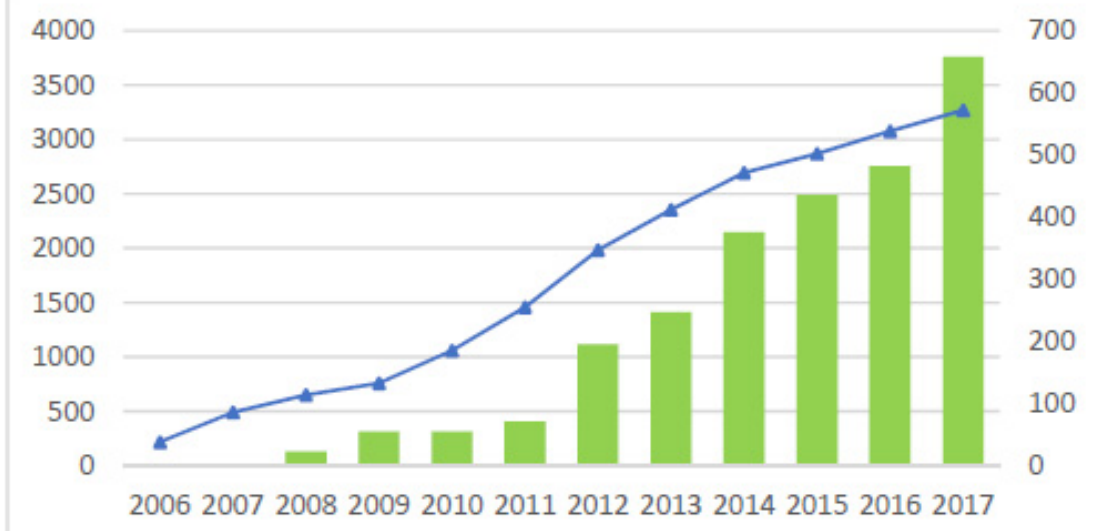

The Amount of Green Credit for the Year (100 million yuan)

$\longrightarrow$ net profit(100 million yuan)

Figure 1. Green Credit Scale and Net Profit

As can be seen from the figure, the initial growth rate of the Industrial Bank's green credit is relatively fast. Since 2012, the amount of green credit increased significantly, which has formed a certain scale. The amount in 2017 is equivalent to nearly 10 times that of 2011 . Focusing on green finance for many years, Industrial Bank has maintained its leading position in the industry, and its brand advantage and comprehensive strength have been further expanded.

Green credit will not only affect the size of commercial banks' assets, but may also have a significant impact on net profit. Green credit means that more funds will be allocated to low-carbon environmental protection enterprises. These enterprises are small in scale and uncertain, and there are certain loan risks. However, the figure shows that after the development of green finance, the net profit of Industrial Bank is still rising. From 2006 to 2011, it showed a rapid growth trend. The net profit growth in 2006 and 2007 was particularly rapid. This may be because Industrial Bank took the lead in entering the market and seized most of the market share. From 2013 to 2015, the profit growth rate slowed down due to factors such as changes in the macro environment and Internet financial shocks. The growth rate of green credit is obviously greater than the growth rate of net profit, which indicates that green credit will increase the cost of bank operations in the short term and affect the growth of profits. However, in the long run, it will contribute to the increase of profits after having a certain scale effect.

In addition, the development of green credit has created good environmental benefits, and the amount of investment has a positive correlation with the contribution to the environment. Along with the expansion of the scale of green credit, annual savings in standard coal, annual carbon dioxide emission reduction, annual comprehensive utilization of solid waste, and annual water saving continue to increase, which has effectively improved resource utilization efficiency and promoted energy conservation and emission reduction. As of the end of 2017, Industrial Bank has provided green financing to more than 14,000 companies, totaling over RMB 140 billion. The supported projects have significant environmental benefits, achieving annual savings of 29.12 million tons of standard coal, reducing $\mathrm{CO} 2$ emissions by 83.78 million tons, and saving water resources by 40.84 million tons. 


\section{Methods}

\subsection{Hypothesis}

In the past literature on the impact of green credit on the financial performance of commercial banks, most scholars hold a positive attitude, believing that green credit will effectively reduce the environmental risks of the banking industry and improve financial performance. Williams et al. (2013) point out that green credit is necessary for the development of commercial banks, and it is also beneficial in the long run. It can enhance the economic benefits of banks and promotes sustainable development. Ma P and Jiang H (2009) construct the short-term marginal cost curve and short-term marginal benefit curve of commercial banks. It is found that the bank's implementation of green credit policy will increase its own cost and reduce profits in the short term, but the brand effect and product difference generated in the long run. The effect can improve the competitive advantage of enterprises and increase their income. S Li (2015) obtains empirically that practicing green finance can indeed reduce risks and have a positive impact on bank performance. At the same time, he compares the bank's performance before and after the development of green financial products. It is showed that after the emergence of green financing new products, the performance is better than when there is no time. Based on the above theoretical basis, this paper proposes the following hypothesis: the development of green credit, promote the financial performance of commercial banks.

\subsection{Dependent Variable: Return on Capital (ROA)}

Listed companies generally use indicators such as return on capital (ROA), return on shareholder (ROE), and TOBIN Q to measure financial performance. Since China's commercial banks generally rely on the difference between deposit and loan interest to obtain profit, the ROA reflects the profitability more realistic, reflecting how much net profit each unit of assets can bring.

\subsection{Independent Variable: Green Credit Ratio (GLR)}

Use green credit ratio to reflect the size of green credit. Green credit can improve the bank's credit structure, reduce the loan amount of the "two highs and one surplus" industry, and rationally guide resources to the circular economy, low-carbon economy, and ecological economic flow. This not only promotes green development, but also provides a way for commercial banks to improve their financial performance. On this basis, green credit will have a certain impact on the bank's reputation, help build a green brand, foster core competitiveness, and enhance market position.

\subsection{Control Variables}

Previous research has indicated that capital size, capital status, capital quality, profitability can affect the return on capital. Hence, we formed additional independent variables as control variables.

Table 1. Measurement of variables.

\begin{tabular}{ccc}
\hline Variable & Name & Measurement \\
\hline Green Credit Ratio & GLR & Total green credit / Total loan amount \\
Profitability & ROA & Net profit / Total assets \\
Company size & TA & Ln(Total assets) \\
Capital Status & CCAR & Bank Core Capital / Weighted Risk Assets \\
Capital Quality & NPLR & Non-performing loan amount / Total loan amount \\
Profitability & EPS & After-tax profit / Total share capital \\
\hline
\end{tabular}

\subsection{Model}

The data comes from the CSMAR database, the Industrial Bank's annual report and the CSR annual report for the period 2005-2017. The model is as follows:

$$
\mathrm{ROA}=\alpha+\beta_{1} \mathrm{GLR}+\boldsymbol{\beta}_{2 \mathrm{NPLR}}+\boldsymbol{\beta}_{3} \mathrm{CCAR}+\boldsymbol{\beta}_{4} \mathrm{TA}+\boldsymbol{\beta}_{5} \mathrm{EPS}+\varepsilon
$$




\subsection{Descriptive Statistics}

Table 2. Correlation coefficients of all variables.

\begin{tabular}{ccccccc}
\hline & ROA & GLR & NPLR & CCAR & TA & EPS \\
\hline ROA & 1 & & & & & \\
GLR & 0.187 & 1 & & & & \\
NPLR & $-0.850^{* *}$ & 0.096 & 1 & & & \\
CCAR & $0.923^{* *}$ & 0.402 & $-0.667^{*}$ & 1 & & \\
TA & 0.246 & $0.992^{* *}$ & 0.025 & 0.471 & 1 & \\
EPS & $0.617^{*}$ & 0.526 & -0.477 & $0.761^{* *}$ & 0.568 & 1 \\
\hline$* \mathrm{p}<0.05, * * \mathrm{p}<0.01$ & & & & &
\end{tabular}

It can be seen from the relevant analysis that there is a positive correlation between the ROA of the bank and CCAR, EPS, which are significant at the level of $1 \%$ and $5 \%$ respectively. There is a negative correlation between ROA and NPLR, which is significant at the $1 \%$ level. However, it is regrettable to find that the correlation between ROA and GLR is not significant. Simple correlation does not control other variables and does not necessarily reflect the real situation, so more factors should be considered.

\subsection{Principal Component Analysis}

Table 3. Principal component analysis results

\begin{tabular}{ccccccc}
\hline \multirow{2}{*}{ component } & \multicolumn{5}{c}{ Initial eigenvalue } & \multicolumn{3}{c}{ Extract square sum loading } \\
\cline { 2 - 7 } & Total & Variance $\%$ & Cumulative \% & Total & Variance \% & Cumulative \% \\
\hline 1 & 2.994 & 59.878 & 59.878 & 2.994 & 59.878 & 59.878 \\
2 & 1.543 & 30.866 & 90.743 & 1.543 & 30.866 & 90.743 \\
3 & .281 & 5.619 & 96.363 & & & \\
4 & .177 & 3.543 & 99.906 & & & \\
5 & .005 & .094 & 100.000 & & & \\
\hline
\end{tabular}

Table 4. Composition of the first and second principal component coefficients

\begin{tabular}{ccc}
\hline & \multicolumn{3}{c}{ Component } \\
\cline { 2 - 3 } & 1 & 2 \\
\hline GLR & 0.795 & 0.588 \\
NPLR & -0.441 & 0.834 \\
CCAR & 0.839 & -0.426 \\
TA & 0.837 & 0.526 \\
EPS & 0.874 & -0.209 \\
\hline
\end{tabular}

The first two eigenvectors can be calculated from the total variance of the component matrix and the table. The first two principal component expressions are obtained by dividing the square roots of the previous two eigenvalues by the first two columns of the component matrix:

$$
\begin{aligned}
& F_{1}=0.795 \text { GLR }-0.441 \text { NPLR }+0.839 C C A R+0.837 T A+0.874 E P S \\
& F_{2}=0.588 G L R+0.834 N P L R-0.426 C C A R+0.526 T A-0.209 E P S
\end{aligned}
$$

Regression is performed again, and the $\mathrm{R} 2$ after the regression equation adjustment is 0.851 . The linear regression of ROA for the two principal components was $\mathrm{p}<0.001$. Through the significance test, there was no multicollinearity and the regression coefficient was reasonable. The principal component regression equation can be obtained:

$$
R O A=1.065+0.083 F 1-0.109 F 2
$$

The equations of $\mathrm{F} 1$ and $\mathrm{F} 2$ are brought into the regression equation about the normalized independent variable to obtain the restored regression equation:

$$
R O A=1.065+0.0596 \text { GLR }-0.0457 \text { NPLR + 0.0743CCAR + 0.0637 TA + 0.0726 EPS }
$$




\subsection{Analysis}

In summary, the coefficient of the GLR is 0.0596 , which confirms the previous assumption that the development of green credit will help improve financial performance. If one unit GLR is added, the return on assets will increase. The coefficient of CCAR is 0.0743 , which shows a positive correlation between financial performance and core capital adequacy ratio. CCAR represents the rationality of the bank's capital structure and the risks of bank operations. The better the capital position, the higher the financial performance. EPS is also positively correlated with financial performance, which most intuitively reflects the bank's operations and profitability. There is a negative correlation between NPLR and the ROA, with a coefficient of -0.0457 . It is obvious that the higher the NPLR, the lower profitability and the ROA.

From the results, green credit and bank financial benefits have a positive relationship. It is for this reason that Industrial Bank spares no effort to adhere to the path of green development, and regards green credit as its long-term development strategy, and continues to promote the adjustment of green credit; since 2008, the loans of the "two high and one surplus" industries have been strictly controlled, and the concentration of loans to industries such as steel, cement and chemical raw materials has been declining.

\section{Conclusions}

Based on the case of Industrial Bank, this paper finds a positive correlation between green credit and financial performance through a simple empirical test. Facing the challenges of future economic growth and sustainable development, promoting the development of green credit will become an inevitable trend in the development of the financial industry. Under the leadership of the central bank and the China Banking Regulatory Commission, more banking financial institutions began to transform into green development. However, it is undeniable that the development of green credit still has problems of insufficient products and inadequate management systems. To this end, for the practice of the banking industry, this paper proposes the following recommendations: First, innovative green credit products to meet market demand. Banking financial institutions need to take into account economic and social benefits in designing products according to the current market conditions, embody environmental and social responsibility awareness, and meet the diversified needs of customers. Second, improve the organizational structure and the level of green credit management. Commercial banks should do adequate planning and preparation, establish a green internal process and a complete institutional system; introduce high-paying professionals who are good at enterprise project evaluation, and carry out green financial capacity building to make up for the shortcomings of talent shortage and immature technology; promote green concepts within the bank, Cultivate employees' awareness of green environmental protection and use actual actions to reduce carbon emissions in daily operations.

\section{References}

[1]. DX He, XL Zhang. Reflections on Several Issues Concerning the Implementation of Green Credit in China's Commercial Banks [J]. Shanghai Finance, 2007(12):4-9.

[2]. Miles M P, Coven J G. Environmental Marketing: A Source of Reputational, Competitive, and Financial Advantage [J]. Journal of Business Ethics, 2000, 23(3):299-311.

[3]. XH Shen. Green Credit, Green Reputation and Bank Performance [D]. Nanjing: Nanjing University of Finance and Economics, 2012: 29-30.

[4]. S Li. The impact of the implementation status of China's listed banks' green credit policies on their business performance [D]. Zhejiang Gongs hang University, 2015: 35-36.

[5]. Ma P, Jiang H. Green Credit and Social Responsibility--an Analysis Based on Commercial Banks [J]. Contemporary Economy \& Management, 2009, 31(6): 70-73. 
[6]. Williams C A. Regulating the Impacts of International Project Financing: The Equator Principles [J]. Proceedings of the Sail Annual Meeting, 2013, 107(2):303-308. 